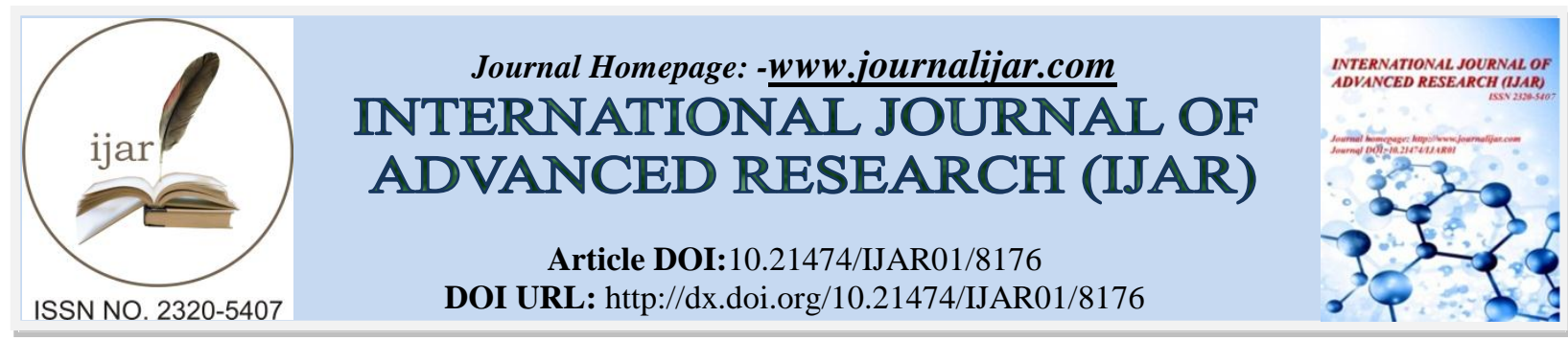

RESEARCH ARTICLE

\title{
POTENTIAL CHLORPYRIFOS AND MALATHION DEGRADING BACTERIAL ISOLATION, BIOCHEMICAL CHARACTERIZATION AND GROWTH KINETICS STUDIES.
}

B.Niranjana Reddi and D.Sandya Deepika.

Department of Botany, College of Science and Technology, Andhra University, Visakhapatnam- 530003.

\section{Manuscript Info}

\section{Manuscript History}

Received: 08 October 2018

Final Accepted: 10 November 2018

Published: December 2018

\section{Keywords:-}

bacterial isolation, chlorpyrifos, malathion, pesticide degradation, growth kinetics, biochemical characterization

\section{Abstract}

Soil bacterium capable of utilizing organophosphate based pesticides as sole carbon source was isolated by selective enrichment on mineral medium containing chlorpyrifos and malathion individually. A total eleven bacterial isolates were isolated from five different agriculture soils. The pesticide tolerance test revealed that MGPD-02 was high potential isolate against chlorpyrifos and malation, biochemical characteristics revealed that MGPD-02 was gram negative bacilli citrate, nitrate reductase, MR and VP positive bacteria. Growth studies showed that MGPD-02 utilized chlorpyrifos to grow in Luria-Bertani broth containing different concentrations of chlorpyrifos at $50-500$ ppm. However, the optimum concentration that supported bacterial growth over $24 \mathrm{~h}$ was found to be $50-200 \mathrm{ppm}$. Further concentrations were proved to be decreasing their bacterial growth and become completely lethal at $500 \mathrm{ppm}$ for both chlorpyrifos and malathion.

Copy Right, IJAR, 2018,. All rights reserved.

\section{Introduction:-}

The extensive use of pesticides has a potential to severely contaminate soil and causes to dicrease in the microbial diversity (Brice no et al., 2012). Pesticides are known to adversial affects such as soil fertility loss due to microbial diversity decrease and stunted plant growth, which in turn put the sustainability of agricultural soil at serious risk (Fang et al., 2009). Numerous reports advise that soils were contaminated by these pesticides as a result of these usage may lead to occasional contamination of a wide range of water and terrestrial ecosystems (Singh et al., 2004)

Chlorpyrifos (CP) and Malathion (MT) are broad spectrum organophosphates (OPPs) insecticides those are classified as moderately toxic. Since $19^{\text {th }}$ century these pesticides were extensively used in the agricultural sector for controlling insect infestations of crops such as cotton, cereals, vegetables and fruits (Jabeen et al., 2015). OPPs can cause neurotoxic effects by inhibiting the acetylcholinesterase enzyme (González-Alzaga et al., 2014). Yet, other toxicities (e.g. immunotoxicity, genotoxicity, and carcinogenicity) have also been observed in chronic exposure to lower doses of OPPs. And those have been shown to be harmful to both animals and humans (Saulsbury et al., 2008). OPPs are also been reported that they reduction microbial population and diversity in the soil and is known to slow down nitrogen mineralization in soil (Menon et al., 2004).

For the above reasons, the OPPs degradation is need of the in concern to human health and soil microbial diversity development. OPPs degradation is achieved by applying physiochemical and biological methods. Microbial 
degradation of pesticides is exploits the potential of microbial degradation for providing a cost-effective and reliable approach to pesticide abatement. Several soil and aquatic environments have been successfully reclaimed from pesticide contamination by using microbes capable of degrading the pollutants. Hydrolysis, either chemically or as a result of microbial activity, degrades CP by converting it to diethylthiophosphoric acid (DETP) and 3,5,6-trichloro-2-pyridinol (TCP) (Anwar et al., 2009). Microbial degradation of MT gives two main degradation products namely malathion monocarboxylic acid (MMA) and malathion dicarboxylic acid (MDA), the first one may convert to the latest one over time. Some other degradation products may occur such as ethyl hydrogen fumarate (EHF) but in negligible amount (Tamer et al., 2013).

The objectives of the present study were to isolate CP and MT degrading bacteria from different agriculture soils and biochemical characterization of those bacterial isolates.

\section{Materials And Methods:- \\ Sample:-}

Five soil samples were collected from the agriculture areas where chlorpyrifos and malathion were used as pesticide from past five to ten years i.e. Anandhapuram, Vellanki, Tallavalasa, Padmanabham and Kothha valasa.

\section{Pesticide used:-}

Commercial grade insecticide chlorpyrifos (50\% E.C.) and malathion (30\% E.C.) were used in this study. They were used throughout the experimental studies, because it may more closely resemble the active compound that microorganisms are likely to be exposed to in the soil environment.

\section{Media:-}

Mineral salts medium (MSM) enriched with chlorpyrifos and malathion were used for isolation and characterization of chlorpyrifos and malathion degrading bacteria. The carbon source in MSM was replaced with chlorpyrifos and malathion in different concentrations. The MSM has the following composition in $(\mathrm{g} / \mathrm{L})$ : KH2PO4, 4.8; K2HPO4, 1.2; NH4NO3, 1.0; MgSO4.7H2O. 0.2; Ca (NO3)2.4H2O, 0.04; and Fe (SO4)3, 0.001 with pH 7.0 (Rasul et al., 1988)

Culture enrichment and isolation of chlorpyrifos and malathion degrading bacteria from soil samples:-

Five soil samples were serially diluted and third dilution was inoculated into MS media which contains $0.25 \%$ of chlorpyrifos/malathion and $0.75 \%$ of glucose as carbon source and incubated in orbital shaker for three days at $28^{\circ} \mathrm{C}$ and $240 \mathrm{rpm}$. Then $100 \mu 1$ of samples for the above treatments were transferred into fresh tube containing MS media with $0.5 \%$ of chlorpyrifos/malathion and $0.5 \%$ of glucose and incubated in orbital shaker for three days at $28^{\circ} \mathrm{C}$ and $240 \mathrm{rpm}$. Then from the above treatments $100 \mu \mathrm{l}$ of sample was transferred into fresh tube containing MS media with $0.25 \%$ of chlorpyrifos/malathion and $0.75 \%$ of glucose and incubated in orbital shaker for three days at $28^{\circ} \mathrm{C}$ and $240 \mathrm{rpm}$. Finally $100 \mu \mathrm{l}$ of sample was inoculated fresh tube containing MS media with $1 \%$ of chlorpyrifos/malathion and incubated in orbital shaker for three days at $28^{\circ} \mathrm{C}$ and $240 \mathrm{rpm}$. After incubation 100 $\mu 1$ from each treatment were spread separately onto mineral agar supplemented with chlorpyrifos $(50 \mathrm{mg} / \mathrm{L})$ and mineral agar supplemented with malathion $(50 \mathrm{mg} / \mathrm{L})$ and plates were incubated at $37^{\circ} \mathrm{C}$ for $24 \mathrm{~h}$.

\section{Biochemical characterization of isolated bacteria:-}

The individual bacterial colonies that grew on the medium were sub-cultured onto mineral agar containing chlorpyrifos of the same concentration until pure cultures were obtained. Bacterial isolates were subjected to morphological, cultural and biochemical studies.

\section{Viable cell count determinations:-}

Aliquots $(2.5 \mathrm{ml})$ of $24-\mathrm{h}$ old bacterial cultures grown in mineral salts medium were inoculated into $100-\mathrm{ml}$ Erlenmeyer flasks containing $25 \mathrm{ml}$ of Luria-Bertani broth supplemented with various concentrations (50 - 700 $\mathrm{mg} / \mathrm{L}$ ) of chlorpyrifos and malathion to test their ability to degrade the supplemental substrate (pesticide). A control was maintained with equal volume of broth containing bacterial culture, but without pesticide. Bacterial growth was followed by viable cell counts immediately after inoculation at $0 \mathrm{~h}$ and 2, 4, 6 and $24 \mathrm{~h}$ of incubation. A bacterial inoculum $(1 \mathrm{ml})$ was drawn at regular intervals from the test and control cultures and serial dilutions were performed using $9 \mathrm{ml}$ of sterile saline $(0.85 \% \mathrm{NaCl}$; $\mathrm{pH} 7)$. Appropriate dilutions were plated in triplicate on nutrient agar and the plates incubated at $37^{\circ} \mathrm{C}$ for $24 \mathrm{~h}$. The bacterial colonies were counted as colony forming units (CFU/ml) with a colony counter, as described by Collins and Lynes (1985). 


\section{Results And Discussion:-}

Eleven different chlorpyrifos and malathion degrading bacterial isolates were isolated based on the morphological colony characters from the collected five soil samples using the culture enrichment technique (Figure-1). All bacterial isolates were common to the both pesticides because these two pesticides were belongs to organophosphates family.

All these eleven isolates were showed distinguish difference at biochemical level characters. In the eleven isolates three isolates were cocci shaped and remaining eight were rod shaped bacteria. On the other hand five bacteria were gram negative bacteria and six bacteria were gram positive bacteria. All eleven bacteria were utilizing citrate except MGPD-03. In these MGPD-6, 7, 10 and 11 isolates were hydrolyzing starch and rest of the seven isolates were not able to hydrolyzing starch. All eleven bacteria were nitrate reducing bacteria only. MGPD- 3, 4, 5 and 10 isolates were negative to methyl red and remaining isolates were showing positive result to methyl red, on the other hand MGPD- 3, 4 and 10 isolates were negative to VP and remaining isolates were showing positive result to VP (Table-1).

\section{Growth kinetics studies of MGPD-02:-}

Growth curve experiments were performed to confirm the high pesticide tolerance isolate and to determine the optimum concentration of chlorpyrifos and malathion that stimulates the growth MGPD-02. A Similar strategy has been reported previously by (Karpouzas et al.,2000; Haugland et al., 1990) while performing pesticide degradation using isolated strains of microorganisms.

At 200 ppm all eleven isolates show visible growth both in chlorpyrifos and malathion treatments. Upto 6 hours the growth was gradually increasing, and the growth was variable for each isolate. Between 6 hours and 24 hours the growth was dynamically increased. At 24 hours MGPD-02 maximum viable count in both chlorpyrifos and malathion amended conditions, the viable counts were $116.09 \times 10^{6}$ and $98.46 \times 10^{6}$ consequently. These viable counts were very high when compared to the rest of the all isolates. So further pesticide tolerance growth kinetics studies were carried with MGPD-02.

By observing the growth kinetics studies we observe that the phase adoption was continued up to $4 \mathrm{~h}$ and the total viable count at the initial period was $5.8 \times 10^{6} \mathrm{CFU} / \mathrm{ml}$ in chlorpyrifos and $9.16 \times 10^{6}$ in malathion at $50 \mathrm{ppm}$ concentration (Table 3 and 5). After incubation for $6 \mathrm{~h}$, the total viable counts were $51.23 \times 10^{6}$ and $40.28 \times 10^{6}$ $\mathrm{CFU} / \mathrm{ml}$ for chlorpyrifos and malathion consequently. The bacterium had a generation time of $77.2 \mathrm{~min}$ and specific growth rate $(\mu)$ of $0.017 / \mathrm{h}$. (Mansi and Bryce, 2002). With increasing incubation time the bacterial growth also improved. For instance, after incubation for $24 \mathrm{~h}$ the total viable count increased significantly decrease from $50 \mathrm{ppm}$ to $500 \mathrm{ppm}$. This indicated that the bacterial culture, after remaining in lag phase (phase of adjustment to initiate accelerated growth) for $5 \mathrm{~h}$, entered into the $\log$ phase. The total viable count of $5.08 \times 10^{6} \mathrm{CFU} / \mathrm{ml}$ at $4 \mathrm{~h}$ had increased to $51.23 \times 10^{6} \mathrm{CFU} / \mathrm{ml}$ at $6 \mathrm{~h}$, and to $369.88 \times 10^{6} \mathrm{CFU} / \mathrm{ml}$ at $24 \mathrm{~h}$ in chlorpyrifos, on the other hand the total viable count of $9.16 \times 10^{6} \mathrm{CFU} / \mathrm{ml}$ at $4 \mathrm{~h}$ had increased to $40.28 \times 10^{6} \mathrm{CFU} / \mathrm{ml}$ at $6 \mathrm{~h}$, and to $298.69 \times 10^{6}$ $\mathrm{CFU} / \mathrm{ml}$ at $24 \mathrm{~h}$ in malathion. These results revealed that MGPD-02 growth was higher in chlorpyrifos than malathion. The generation time was calculated to be $137 \mathrm{~min}$ at $50 \mathrm{mg} / \mathrm{L}$ and $165 \mathrm{~min}$ at $200 \mathrm{mg} / \mathrm{L} \mathrm{of}$ chlorpyrifos, respectively (Mansi and Bryce, 2002). The results also indicated that growth of the bacterial isolate in the presence of chlorpyrifos was stimulated in the concentration range of $50-200 \mathrm{mg} / \mathrm{L} \mathrm{during} 24 \mathrm{~h}$ of incubation (Figure 3). The total viable count at $24 \mathrm{~h}$ was $369.88 \times 10^{6}, 175.63 \times 10^{6}, 116.09 \times 10^{6}, 65.20 \times 10^{6}$, $3.68 \times 10^{6}$ and $0.27 \times 10^{6}$ with $50 \mathrm{ppm}, 100 \mathrm{ppm}, 200 \mathrm{ppm}, 300 \mathrm{ppm}, 400 \mathrm{ppm}$ and 500 ppm respectively for chlorpyrifos and $298.69 \times 10^{6}, 216.05 \times 10^{6}, 98.46 \times 10^{6}, 41.58 \times 10^{6}, 2.01 \times 106$ and $0.00 \times 10^{6}$ with 50 ppm, 100 ppm, 200 ppm, 300 ppm, 400 ppm and 500 ppm respectively for malathion. These observations indicated that the rate of substrate utilization decreased, which prolonged the lag phase in the presence of higher concentrations of chlorpyrifos. As growth kinetic studies providing an evidence of mineralization potential of organism, therefore such studies were reported by several other researchers (Maria et al., 2002; Karpouzas et al., 2000; Lee et al., 1992; Smith et al., 1996) while performing pesticide degradation using isolated strains of microorganisms.

The results obtained in this study were in agreement with earlier reports that indicated the involvement of different species of Enterobacteriaecae in the degradation of organophosphorous insecticides like chlorpyrifos (Singh et al., 2004), phosphonate (Lee et al., 1992) and glyphosate (Dick and Quinn, 1995). Singh et al. (2004) reported that Enterobacter strain B-14 used chlorpyrifos as a source of carbon and phosphorous. Sethunathan and Yoshida (1973) isolated a Flavobacterium sp. that could use parathion as source of phosphorous but not diazinon 
as carbon source. Although utilization of chlorpyrifos and malathion by several soil bacteria has been reported (Singh et al., 2004; Sethunathan, 1973; Racke et al., 1990).

A possible explanation may be that microorganisms need an adaptation period to produce the necessary degradative enzymes. This may account for the prolonged lag phase at high concentrations of added chlorpyrifos (Jilani and Khan, 2004). Degradation of different pesticides at high concentrations by microorganisms has been reported previously (Karpouzas et al.,2000; Struthers et al., 1998). Enterobacter sp. was able to degrade chlorpyrifos at concentrations as high as $250 \mathrm{mg} / \mathrm{L}$ in less than two days (Singh et al., 2004). In the presence of high concentrations of insecticides, the bacterium was greatly stressed and its growth was slowed as a consequence. During the adaptation period, the bacteria changed from a rod shape to a coccus form with an increase in insecticide concentration (Jilani and Khan, 2004). However, this change was temporary and after seven days the strain recovered to its original rod shape. The soil used for the present study had been exposed to chlorpyrifos for about ten years. Hence, the tolerance of the organism might be due to previous exposure or due to its ability to hydrolyze the supplemental substrate. Successful removal of pesticides by the addition of bacteria had been reported earlier for many compounds, including coumaphos (Mulbry et al., 1996), ethoprop (Karpouzas et al., 2000) and atrazine (Struthers et al., 1998).

Table 1:-Biochemical characters of eleven bacterial isolates

\begin{tabular}{|l|c|c|c|c|c|c|c|c|c|c|c|}
\hline Test name & $\begin{array}{c}\text { MGPD- } \\
01\end{array}$ & $\begin{array}{c}\text { MGPD- } \\
02\end{array}$ & $\begin{array}{c}\text { MGPD- } \\
03\end{array}$ & $\begin{array}{c}\text { MGPD- } \\
04\end{array}$ & $\begin{array}{c}\text { MGPD- } \\
05\end{array}$ & $\begin{array}{c}\text { MGPD- } \\
06\end{array}$ & $\begin{array}{c}\text { MGPD- } \\
07\end{array}$ & $\begin{array}{c}\text { MGPD- } \\
08\end{array}$ & $\begin{array}{c}\text { MGPD- } \\
09\end{array}$ & $\begin{array}{c}\text { MGPD- } \\
10\end{array}$ & $\begin{array}{c}\text { MGPD- } \\
11\end{array}$ \\
\hline Shape & Cocci & Bacilli & Bacilli & Bacilli & Cocci & Bacilli & Bacilli & Cocci & Bacilli & Bacilli & Bacilli \\
\hline $\begin{array}{l}\text { Grams } \\
\text { Stain }\end{array}$ & + & - & - & - & - & + & + & - & + & + & + \\
\hline Citrate & + & + & - & + & + & + & + & + & + & + & + \\
\hline $\begin{array}{l}\text { Starch } \\
\text { hydrolysis }\end{array}$ & - & - & - & - & - & + & + & - & - & + & + \\
\hline $\begin{array}{l}\text { Nitrate } \\
\text { reductase }\end{array}$ & + & + & + & + & + & + & + & + & + & + & + \\
\hline $\begin{array}{l}\text { MR(Methyl } \\
\text { red) }\end{array}$ & + & + & - & - & - & + & + & + & + & - \\
\hline $\begin{array}{l}\text { VP(voges } \\
\text { proskauer) }\end{array}$ & + & + & - & - & + & + & + & + & + & + \\
\hline
\end{tabular}

Table2:-Effect of Chlorpyrifos at 200 ppm against eleven bacterial isolates growth kinetics

\begin{tabular}{|c|c|c|c|c|c|}
\hline \multirow{2}{*}{ S.No } & \multirow{2}{*}{$\begin{array}{c}\text { Bcaterial } \\
\text { Isolates }\end{array}$} & \multicolumn{5}{|c|}{ Viable bacteria x 10 } \\
\cline { 3 - 6 } & MGPD-01 & 0.12 & $4 \mathrm{hr}$ & $6 \mathrm{hr}$ & $24 \mathrm{hr}$ \\
\hline 1 & MGPD-02 & 0.11 & 2.96 & 5.98 & 12.05 \\
\hline 2 & MGPD-03 & 0.10 & 0.76 & 10.07 & 116.09 \\
\hline 3 & MGPD-04 & 0.05 & 1.09 & 19.06 & 84.69 \\
\hline 4 & MGPD-05 & 0.07 & 0.49 & 3.98 & 19.72 \\
\hline 5 & MGPD-06 & 0.09 & 1.68 & 28.04 & 90.19 \\
\hline 6 & MGPD-07 & 0.11 & 0.60 & 8.29 & 27.99 \\
\hline 7 & MGPD-08 & 0.12 & 0.95 & 8.84 & 30.28 \\
\hline 8 & MGPD-09 & 0.03 & 2.51 & 29.27 & 105.80 \\
\hline 9 & MGPD-10 & 0.08 & 1.89 & 20.04 & 80.52 \\
\hline 10 & MGPD-11 & 0.10 & 0.65 & 6.95 & 18.04 \\
\hline
\end{tabular}


Table3:-Effect of chlorpyrifos at different concentrations against MGPD-02 bacterial growth kinetics

\begin{tabular}{|c|c|c|c|c|c|}
\hline \multirow{2}{*}{ S.No } & \multirow{2}{*}{$\begin{array}{c}\text { Pestcide } \\
\text { con. }\end{array}$} & \multicolumn{4}{|c|}{ Viable bacteria x 10 } \\
\cline { 3 - 6 } & & $2 \mathrm{hr}$ & $4 \mathrm{hr}$ & $6 \mathrm{hr}$ & $24 \mathrm{hr}$ \\
\hline 1 & $50 \mathrm{ppm}$ & 0.15 & 5.80 & 51.23 & 369.88 \\
\hline 2 & $100 \mathrm{ppm}$ & 0.14 & 3.21 & 46.20 & 175.63 \\
\hline 3 & $200 \mathrm{ppm}$ & 0.11 & 2.96 & 31.03 & 116.09 \\
\hline 4 & $300 \mathrm{ppm}$ & 0.06 & 1.47 & 14.46 & 65.20 \\
\hline 5 & $400 \mathrm{ppm}$ & 0.06 & 0.16 & 2.79 & 3.68 \\
\hline 6 & $500 \mathrm{ppm}$ & 0.03 & 0.08 & 0.18 & 0.27 \\
\hline
\end{tabular}

Table 4:-Effect of malathion at $200 \mathrm{ppm}$ against eleven bacterial isolates growth kinetics

\begin{tabular}{|c|c|c|c|c|c|}
\hline \multirow{2}{*}{ S.No } & \multirow{2}{*}{$\begin{array}{l}\text { Bcaterial } \\
\text { Isolates }\end{array}$} & \multicolumn{4}{|c|}{ Viable bacteria $\times 10^{6}$} \\
\hline & & $2 \mathrm{hr}$ & $4 \mathrm{hr}$ & $6 \mathrm{hr}$ & $24 \mathrm{hr}$ \\
\hline 1 & MGPD-01 & 0.10 & 3.38 & 14.68 & 35.19 \\
\hline 2 & MGPD-02 & 0.13 & 6.28 & 28.75 & 98.46 \\
\hline 3 & MGPD-03 & 0.10 & 3.79 & 17.06 & 45.86 \\
\hline 4 & MGPD-04 & 0.06 & 1.77 & 10.27 & 29.38 \\
\hline 5 & MGPD-05 & 0.04 & 1.16 & 9.04 & 20.64 \\
\hline 6 & MGPD-06 & 0.05 & 5.61 & 24.05 & 73.06 \\
\hline 7 & MGPD-07 & 0.12 & 1.48 & 8.94 & 19.45 \\
\hline 8 & MGPD-08 & 0.10 & 0.92 & 8.48 & 18.37 \\
\hline 9 & MGPD-09 & 0.06 & 6.13 & 25.49 & 78.26 \\
\hline 10 & MGPD-10 & 0.08 & 5.19 & 21.98 & 63.01 \\
\hline 11 & MGPD-11 & 0.12 & 0.76 & 6.73 & 17.13 \\
\hline
\end{tabular}

Table 5:-Effect of malathion at different concentrations against MGPD-02 bacterial growth kinetics

\begin{tabular}{|c|c|c|c|c|c|}
\hline \multirow{2}{*}{ S.No } & \multirow{2}{*}{$\begin{array}{c}\text { Pestcide } \\
\text { con. }\end{array}$} & \multicolumn{4}{|c|}{ Viable bacteria x 10 } \\
\cline { 3 - 6 } & $2 \mathrm{hr}$ & $4 \mathrm{hr}$ & $6 \mathrm{hr}$ & $24 \mathrm{hr}$ \\
\hline 1 & $50 \mathrm{ppm}$ & 0.19 & 9.16 & 40.28 & 298.69 \\
\hline 2 & $100 \mathrm{ppm}$ & 0.16 & 7.84 & 32.75 & 216.05 \\
\hline 3 & $200 \mathrm{ppm}$ & 0.13 & 6.28 & 28.75 & 98.46 \\
\hline 4 & $300 \mathrm{ppm}$ & 0.09 & 2.40 & 10.29 & 41.58 \\
\hline 5 & $400 \mathrm{ppm}$ & 0.04 & 0.19 & 1.03 & 2.01 \\
\hline 6 & $500 \mathrm{ppm}$ & 0.00 & 0.00 & 0.00 & 0.00 \\
\hline
\end{tabular}


Figure 1:-Chlorpyrifos and malathion added MSM agar plates showing bacterial colonies after 7 days of
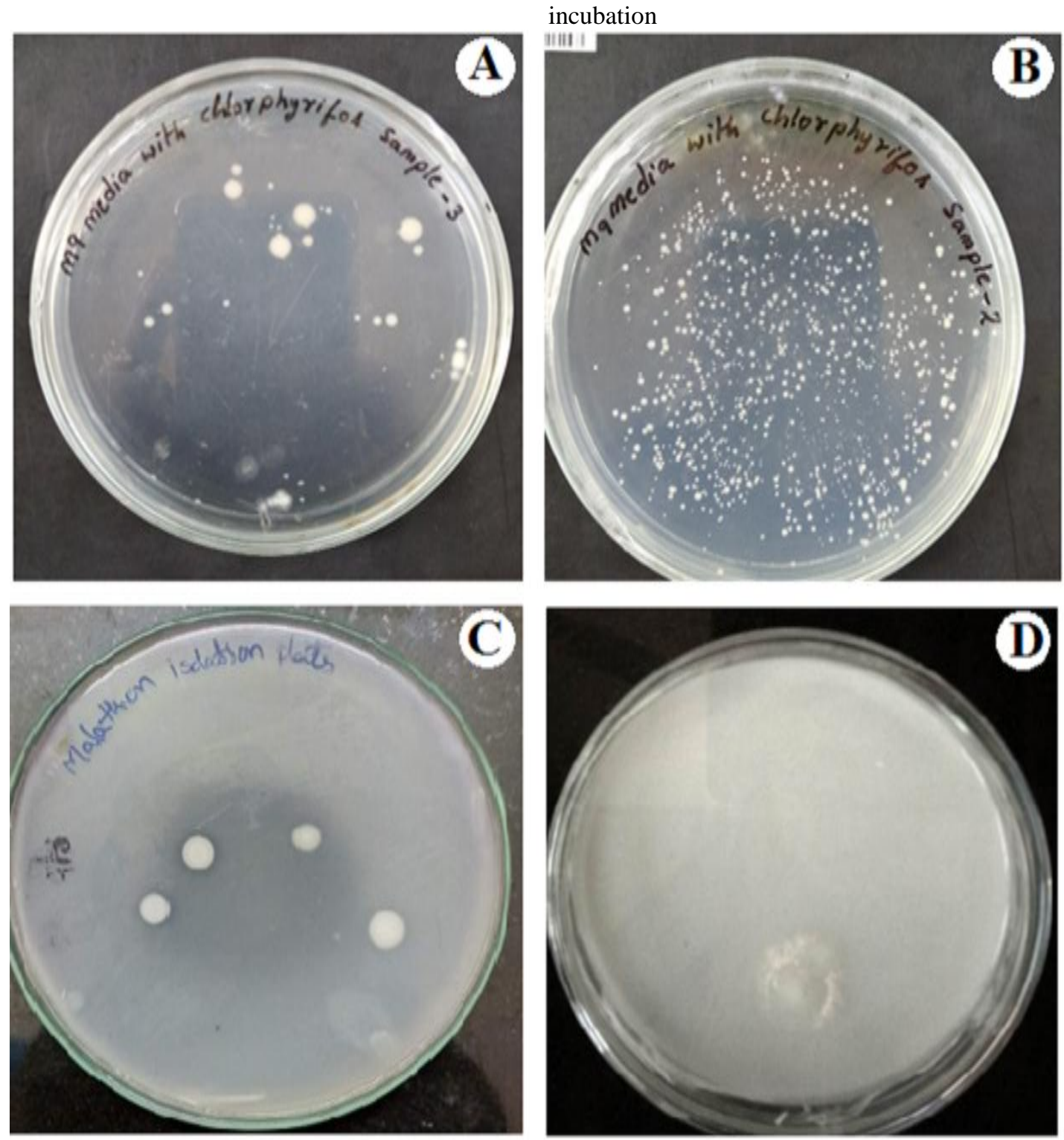

A and B - Showing bacterial colonies in Chlorpyrifos added MS media, C and D showing bacterial colonies in Malathion added MS media.

\section{References:-}

1. Brice no, G., Fuentes, M.S., Palma, G., Jorquera, M.A., Amoroso, M.J. and Dieza, M.C. (2012): Chlorpyrifos biodegradation and 3,5,6-trichloro-2-pyridinol production by Actinobacteria isolated from soil. Int. J. Biodeterior Biodegrad., 73: 1-7.

2. Fang, H., Yu, Y., Chu, X., Wang, X., Yang, X. and Yu, J. (2009): Degradation of chlorpyrifos in laboratory soil and its impact on soilmicrobial functional diversity. J Environ. Sci., 21:380-386.

3. Singh, B.K., Walker, A., Morgan, J.A., Wright, D.J.(2014): Biodegradation ofchlorpyrifos by Enterobacter strain B-14 and its use inbioremediation of contaminated soils. Appl Environ Microbiol., 70:4855-4863.

4. Jabeen, H., Iqbal, S., Anwar, S.(2015): Biodegradation of chlorpyrifosand 3,5,6-trichloro-2-pyridinol by a novel rhizobial strain Mesorhizobium sp HN3. Water Environ J., 29:151-160. 
5. González-Alzaga, B., Lacasaña, M., Aguilar-Garduño, C., Rodríguez-Barranco, M., Ballester, F., Rebagliato, M., Hernández, A. F. (2014): A systematic review of neurodevelopmental effects of prenatal and postnatal organophosphate pesticide exposure. Toxicology letters., 230(2):104-21.

6. Saulsbury, M.D., Heyliger, S.O., Wang, K., Round, D. (2008): Characterization of chlorpyrifos-induced apoptosis inplacental cells. J. Toxicology., 244: 98-110.

7. Menon, P., Gopal, M., Prasad, R.(2004): Influence of two insecticides, chlorpyrifos and quinalphos, on arginine ammonificationand mineralizable nitrogen in two tropical soil types. J. AgricFood Chem., 73707376.

8. Anwar, S., Liaquat, F., Khan, Q. M., Khalid, Z. M. (2009): Iqbal S.Biodegradation of chlorpyrifos and its hydrolysis product3,5,6-trichloro-2-pyridinol by Bacillus pumilus strain C2A1. J.Hazard Mater., 168: 400405.

9. Rasul Chaudhary, G., Ali, A. N., Wheeler, W. B. (1988): Isolation of a methyl parathion-degrading Pseudomonas sp. that possess DNA homologous to the opd gene from a Flovobacterium sp. Appl. Environ. Microbiol., 54: 288- 293.

10. Karpouzas, D.G., Morgan, J. A., Walker, A. (2000): Isolation and characterization of 23 carbofurondegrading bacteria from soils from distant geographical areas. Lett. Appl. Microbiol., 31:353-358.

11. Haugland, R. A., Schlemm, D. J., Lynos, R. P., Sferra, P. R., Chakrabarty, A. M. (1990): Degradation of chlorinated phenoxy acetate herbicides 2, 4- dicholrophenoxy acetic acid and 2, 4, 5- trichloro phenoxy acetic acid by pure and mixed culture. Appl. Environ. Microbiol., 50:1357-1362.

12. Mansi, E. M. T. E. L., Bryce, C. F. A. (2002): Fermentation microbiology and Biotechnology: British library cataloguing in Publications. pp. 49-63.

13. Maria, K., Graciela, C., Zauscher, F. (2002): Biodegradation of two commercial herbicides (Gramoxone and Matancha) by the bacteria Pseudomonas putida. E. J. Env. Biotech., 5(2): 182- 95.

14. Smith-Geer, L. L., Adkins, A. (1996): Isolation and characterization of soil microorganisms capable of utilizing the herbicide dichloro-p-methyl as a source of carbon and energy. Can. J. Microbiol., 42:221-226.

15. Lee, K.S., Metcalf, W.W., Wanner, B. L. (1992): Evidence for two phosphonate degradative pathways in Enterobacter aerogenes. J. Bacteriol., 174(19) :2501-2510.

16. Dick, R. E., Quinn, J. P. (1995): Glyphosate-degrading isolates from environmental samples: ccurrence and pathways of degradation. Appl. Microbiol. Biotechnol., 43(8): 545-550.

17. Sethunathan, N. N., Yoshida, T. (1973): A Flavobacterium that degrades Diazinon and parathion. Can. J. Microbiol., 19:873-875.

18. Racke, K. D., Coats, J. R. (1990): Pesticides in soil microbial ecosystems. Am. Chem. Soc. Symp. Ser., 426:1-12.

19. Jilani, S., Altaf, Khan M. (2004): Isolation, characterization and growth response of pesticide degrading bacteria. J. Biol. Sci., 4(1):15-20.

20. Mulbry, W. W., Del Valle, D. L., Karns, J. S. (1996): Biodegradation of the organophosphorous insecticide coumaphos in highly contaminated soils and in liquid wastes. Pestic. Sci., 48: 149-155.

21. Struthers, J.K., Jayachandran, K., Moorman, T. B. (1998): Biodegradation of atrazine by Agrobacterium radiobacter J14a and use of this strain in bioremediation of contaminated soil. Appl. Environ. Microbiol., 64: 3368-3375.

22. Tamer, M.A., Thabit Medhat, A.H., Naggar, E.L., (2013): Malathion degradation by soil isolated bacteria and detection of degradation products by GC-MS., 3(5): 220- 230. 